\title{
A Comparative Evaluation of Effects of Conventional and Herbal Irrigants on Working Length Determination by Third Generation Apex Locator-An In Vitro Study
}

\author{
Niharika Patalbansi ${ }^{1} \quad$ Yogesh Kumar $^{1} \quad$ Neetu Jindal ${ }^{1}$ \\ ${ }^{1}$ Department of Conservative Dentistry and Endodontics, Surendera \\ Dental College and Research Institute, Sriganaganagar, Rajasthan, \\ India
}

Renu Aggarwal ${ }^{1} \quad$ Shefali Goyal ${ }^{1}$

Dent J Adv Stud 2020;8:44-48

\begin{abstract}
Keywords

- conventional Irrigants

- electronic apex locator

- herbal irrigants

- working length

Introduction The establishment of accurate working length is one of the most critical steps in endodontic therapy from the biomechanical and obturation points of view. Traditionally, the use of radiography and tactile sense methods were used for working length estimation, but recently, the use of electronic apex locator (EAL) has come into existence. The aim was to evaluate the effect of conventional and herbal irrigants on working length determination by Root ZX.

Materials and Methods A total of 110 extracted single rooted teeth were taken. Standard access cavities were prepared and samples were randomly divided into 11 groups ( $n=10$ ) according to the type of irrigating solutions used. The actual root canal length was measured, and the readings in dry conditions and wet conditions were recorded. The point where Root ZX showed beep was recorded and difference was recorded as well. The recorded data was calculated and statistically analyzed using unpaired $t$-test.

Result In dry conditions, only saline, $\mathrm{H}_{2} \mathrm{O}_{2}$, Aloe vera, and green tea gave exact working length using apex locator values. Whereas in wet conditions, only Aloe vera and green tea gave exact working length.

Conclusion Although the irrigants and dry conditions influenced the results, Root ZX can be considered to be accurate, and the difference was within the clinically acceptable range and not statistically significant.
\end{abstract}

\begin{abstract}
Address for correspondence Niharika Patalbansi, MDS, Department of Conservative Dentistry and Endodontics, Surendera Dental College and Research Institute, Sriganaganagar 335001, Rajasthan, India (e-mail: npatalbansi@gmail.com).
\end{abstract}

\section{Introduction}

The working length is considered the distance between a coronal reference point and the apical level, to obtain instrumentation and obturation limit. ${ }^{1}$ The cemento-dentinal junction (CDJ) is thought to be the ideal limit for endodontic instrumentation, because of the narrow constriction of the root canal at that point. It is generally accepted that root canal procedures should be limited to the confines of the root canal system for which an accurate working length is of the utmost importance. ${ }^{2}$ Traditional methods for establishing the working length include the use of radiography and knowledge of anatomy, tactile sensation, and paper point technique. The radiographs provide a two-dimensional (2D) image of a three-dimensional (3D) structure, and the foramen commonly does not coincide with the apex and it does not consistently reveal the end point of root canal systems. To overcome the drawbacks of radiographic method, nowadays, digital electronic apex locators (EAL) are widely used in endodontics. Their functionality is based on the fact that the electrical conductivity of the tissues surrounding the apex of the root is greater than the conductivity inside the root canal systems, provided the canal is either dry or filled with a nonconductive fluid. The third generation apex locators are based on the principle of ratio method where two electric currents 
with different wave frequencies will have measurable impedances that can be measured and compared as a ratio, regardless of the type of electrolyte used for measuring the root canal length, which is the basic working mechanism of Root ZX apex locator. Also, it can work both in dry and wet conditions. A wide variety of conventional antimicrobial agents have been used over the years as endodontic irrigants (3\% Hydrogen Peroxide $\left[\mathrm{H}_{2} \mathrm{O}_{2}\right], 5.25 \%$ Sodium Hypochlorite [ $\mathrm{NaOCl}$ ], 2\% Chlorhexidine [CHX], 19\% EDTA [Ethyledine Diamine Tetraacetic Acid]), but they sometimes irritate the oral environment, cause discoloration, show cytotoxic affects, is unpleasant in taste, and even affect the reading of electronic apex locators due to presence of some salts in irrigants. ${ }^{3}$

Even the herbal products are becoming popular due to their high-antimicrobial activity, biocompatibility, anti-inflammatory, and antioxidants properties. It has been found that natural plant extracts could be used as effective endodontic irrigants. ${ }^{3}$ Therefore, the purpose of this study is to evaluate the accuracy of third generation Electronic Apex Locator in dry conditions and its effect using conventional and herbal irrigants in root canals during working length determination.

\section{Materials and Methods}

A total of 110 extracted human single rooted teeth with intact mature apex, noncarious and freshly extracted due to periodontal disease or orthodontic purposes were taken. The teeth with immature apices, caries, fracture or broken down, restored, root resorption, and multiple canals were excluded from this study.

All the remaining organic residues were removed from external root surface with ultrasonic scaler and after rinsing them with tap water, they were kept in $0.9 \%$ Saline solution until further use. Access cavities were prepared on all the teeth by diamond bur (Dentsply Maillefer, Ballaigues, Switzerland) with high-speed airoter handpiece (NSK, Japan) under water coolant.

Then samples were randomly divided into 11 groups according to the type of irrigating solutions used $(n=10)$.

\author{
Group 1. Dry group \\ Group 2. Normal Saline $0.9 \%$ \\ Group 3. Hydrogen Peroxide 3\% \\ Group 4. Sodium Hypochloride 5.25\% \\ Group 5. Chlorhexidine $2 \%$ \\ Group 6. Liquid EDTA 19\% \\ Group 7. Neem extract solution (Azadiracta indica) \\ Group 8. Aloe vera extract (Aloe barbadensis miller) \\ Group 9. Green tea solution (Camellia sinensis) \\ Group 10. Lemon solution (Citrus limon) \\ Group 11. Tulsi extract (Ocimum sanctum)
}

The actual root canal length was measured by inserting a K-file (Dentsply Maillefer, Ballaigues, Switzerland) until the file tip was just visible at the level of apical foramen under stereomicroscope (Labomed, India); later, the working length was adjusted according to Ingle's radiographic method, that is, $0.5 \mathrm{~mm}$ short.

\section{Preparation of Herbal Irrigants}

1. Preparation of Neem leaf extract: Mature fresh neem leaves were collected and $100 \mathrm{~g}$ of neem leaves were tied in muslin cloth and soaked in $800 \mathrm{~mL}$ of distilled water in a beaker. They were then boiled over low flame till the extract reduced to $400 \mathrm{~mL}$. After the extract cooled down, it was filtered in Whatman filter paper and stored in amber bottle for further usage.

2. Preparation of Aloe vera extract: The pulp was removed from $100 \mathrm{~g}$ of Aloe vera leaves and converted into liquid form in a mixer. The liquid was mixed well with distilled water in 1:5 ratio and used.

3. Preparation of the Green tea extracts: Green tea extract supplied in the form of powder was taken and it was mixed with $100 \mathrm{~mL}$ of sterile boiling distilled water for 5 minutes and filtered.

4. Preparation of Lemon juice: Lemon fruits were freshly squeezed just before use with an electric squeezer.

5. Preparation of Tulsi leaf extract: Tulsi extract for the study was obtained by finely powdering the dried leaves. Then, the powder was macerated with $100 \%$ ethanol followed by filtration.

\section{Working Length Measurement in Dry Root Canals}

To evaluate the accuracy of third generation electronic apex locater in dry conditions, the readings were taken after irrigating the canals with $5 \mathrm{~mL}$ of $0.9 \%$ normal Saline using 27 gauge needle and thorough drying of the canals with paper points (Dentsply Maillefer, Ballaigues, Switzerland).

\section{Working Length Measurement in Wet Root Canals}

Lip clip was attached onto the model and other end of electrode to initial apical file and placed in the wet root canal, which was irrigated using $5 \mathrm{~mL}$ of the respective irrigating solutions according to the groups, and working length measurements were done using Root ZX Electronic Apex Locator (J Morita, MFG Corps, Japan) The point where Root ZX showed beep was recorded (-Fig. 1).

\section{Evaluation of Difference in Actual Working Length and Electronic Working Length Using Different Irrigants}

The difference between actual working length determined by radiographic Ingle's method and working length using Root ZX apex locator after irrigating the canals with the respective irrigants were calculated for each tooth.

(Actual working length) - (Electronic working length after use of irrigants)

Whichever was greater was used as reference and the other was subtracted from greater reading, and difference in the working length was recorded in $\mathrm{mm}$.

\section{Statistical Analysis}

Descriptive data are presented as mean \pm standard deviation (SD) and range value. Unpaired $t$-test was used to compare the mean of two groups. 


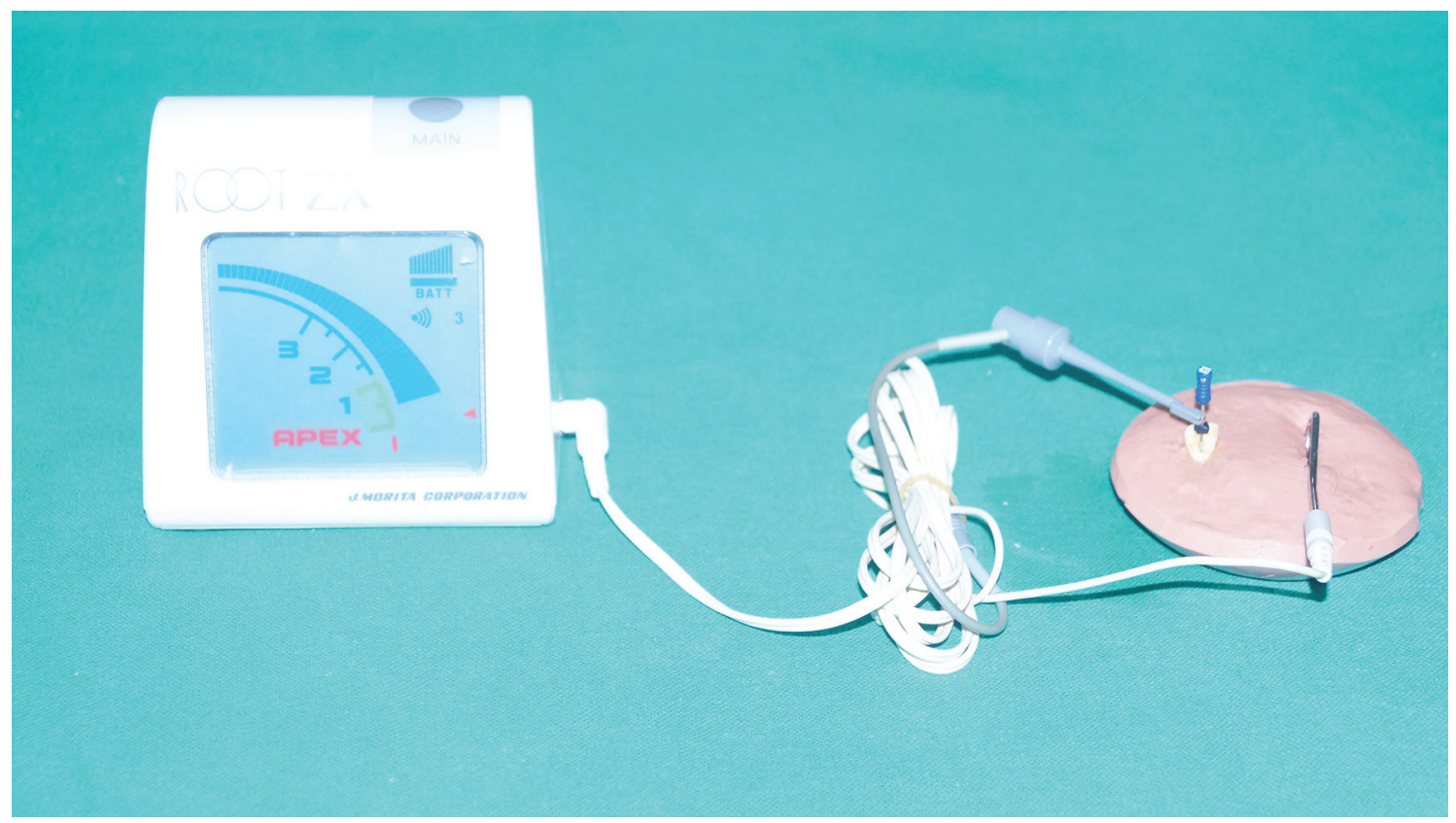

Fig. 1 Experimental setup showing Root ZX apex locator connected to the teeth and mounted on the alginate model.

\section{Results}

If we compare the mean values of working lengths taken with radiographic method and apex locator of all the groups in dry conditions, only saline, hydrogen peroxide, Aloe vera and Green tea gave exact working lengths using apex locator values. However, dry group, sodium hypochlorite, chlorhexidine, EDTA, Neem, Lemon and Tulsi group showed variation in both working lengths, but difference was statistically nonsignificant (- Table 1). Where as in wet conditions, only Aloe vera and Green tea gave exact working lengths. But dry group, saline, hydrogen peroxide, sodium hypochlorite, $\mathrm{CHX}$, EDTA, Neem, Lemon and Tulsi Group (-Table 2) showed minor differences in reading. However, statistically nonsignificant difference was observed between all the groups with $p$ value $>0.05$.

The percentage accuracy in all the groups in dry conditions is $63.6 \%(< \pm 0.5 \mathrm{~mm})$ and in wet conditions is $45.4 \%$ $(< \pm 0.5 \mathrm{~mm})$.

\section{Discussion}

In vitro studies on the accuracy of electronic apex locators are problematic, as the human periodontium is excluded. To minimize drawbacks, several experimental models have been proposed. Alginate provided the most coherent results with the actual working length. Kaufman et al (1997) developed the alginate model, which was used in other studies. Alginate is a good medium to establish the necessary electric circuit for a correct electronic apex locator measurement, because it well mimics the electric impedance of the human periodontium. ${ }^{4}$

In this study, there was not much difference between the values of wet and dry canals but following studies showed Root ZX is more accurate in dry conditions of canal which is actually not feasible clinically. The measurements performed in dry canals were shorter (range of $\geq 0.5 \mathrm{~mm}$ to actual length) for both the apex locators, as seen in the Kaufman et al study. ${ }^{5}$ This is because Haffner et al said in moist canals, there occurs bouncing of needle on display, and the impression during clinical procedure was that the measurement in dry canals was more straightforward and could be done faster. ${ }^{6}$

In clinical conditions, complete drying of moisture is not likely to be achieved because some degree of moisture is bound to be present in the canals due to the hydration of dentin from the surrounding periodontium, but in very dry canals, the signal can drop suddenly nearing the apex or be little unstable. This happens mostly because when the file tip is at extremely dried point, there is little or no electric contact, even at higher frequencies. As soon as it meets with the apical tissue, sudden circuit breaks out, and this, according to Alves at al, brings the signal to the apex mark. ${ }^{7}$

In many groups, there was minor differences in reading which were not statistically significant because $2.5 \% \mathrm{NaOCl}$ was most electroconductive, and the rate of change of impedance in presence of such highly electroconductive solution was not large enough at the apical foramen to result in a clinically detectable reading, according to Goel et al. ${ }^{8}$ Also, Khattak et al opined $\mathrm{NaOCl}$ ionizes in water into $\mathrm{Na}^{+}$and hypochlorous acid, creating acidic $\mathrm{pH} .{ }^{9}$ High-electroconductivity of $\mathrm{NaOCl}$ leads to decrease in the electric impedance of the canal which, in turn, leads to alteration in the electric current flow, according to Dollar et al. ${ }^{10}$

Also, Joshi et al believed hydrogen peroxide has lower conductivity as compared with normal saline, which was the key reason behind their change in range of readings using a third generation electronic apex locator (Propex II). ${ }^{4}$

The 2\% CHX has poor electroconductivity and measurements were longer with both the EALs, according to Mull 
Table 1 The mean and SD values of all groups in dry conditions used for working length determination by radiographic and apex locator methods using unpaired $t$-test.

\begin{tabular}{|c|c|c|c|c|c|c|}
\hline \multicolumn{2}{|c|}{ Dry groups } & Mean & SD & t Value & $p$-Value & Status \\
\hline \multirow{2}{*}{$\begin{array}{l}\text { Group } 1 \\
\text { (dry) }\end{array}$} & Radiographic & 22.950 & 1.771 & \multirow[t]{2}{*}{0.1265} & \multirow[t]{2}{*}{0.9007} & \multirow[t]{2}{*}{ NS } \\
\hline & Apex locator & 22.850 & 1.765 & & & \\
\hline \multirow{2}{*}{$\begin{array}{l}\text { Group } 2 \\
\text { (saline) }\end{array}$} & Radiographic & 23.500 & 1.616 & \multirow[t]{2}{*}{0} & \multirow[t]{2}{*}{1} & \multirow[t]{2}{*}{ NS } \\
\hline & Apex locator & 23.500 & 1.616 & & & \\
\hline \multirow{2}{*}{$\begin{array}{l}\text { Group } 3 \\
\left(\mathrm{H}_{2} \mathrm{O}_{2}\right)\end{array}$} & Radiographic & 21.800 & 1.989 & \multirow[t]{2}{*}{0} & \multirow[t]{2}{*}{1} & \multirow[t]{2}{*}{ NS } \\
\hline & Apex locator & 21.800 & 1.989 & & & \\
\hline \multirow{2}{*}{$\begin{array}{l}\text { Group } 4 \\
(\mathrm{NaOCl})\end{array}$} & Radiographic & 22.150 & 2.461 & \multirow[t]{2}{*}{0.1376} & \multirow[t]{2}{*}{0.8921} & \multirow[t]{2}{*}{ NS } \\
\hline & Apex locator & 22.000 & 2.415 & & & \\
\hline \multirow{2}{*}{$\begin{array}{l}\text { Group } 5 \\
(\mathrm{CHX})\end{array}$} & Radiographic & 21.550 & 1.936 & \multirow[t]{2}{*}{0} & \multirow[t]{2}{*}{1} & \multirow[t]{2}{*}{ NS } \\
\hline & Apex locator & 21.250 & 1.845 & & & \\
\hline \multirow{2}{*}{$\begin{array}{l}\text { Group } 6 \\
\text { (EDTA) }\end{array}$} & Radiographic & 23.100 & 2.481 & \multirow[t]{2}{*}{0.1744} & \multirow[t]{2}{*}{0.8635} & \multirow[t]{2}{*}{ NS } \\
\hline & Apex locator & 22.910 & 2.389 & & & \\
\hline \multirow{2}{*}{$\begin{array}{l}\text { Group } 7 \\
\text { (Neem) }\end{array}$} & Radiographic & 22.200 & 2.071 & \multirow[t]{2}{*}{0.2355} & \multirow[t]{2}{*}{0.8165} & \multirow[t]{2}{*}{ NS } \\
\hline & Apex locator & 21.980 & 2.106 & & & \\
\hline \multirow{2}{*}{$\begin{array}{l}\text { Group } 8 \\
\text { (Aloe V) }\end{array}$} & Radiographic & 23.500 & 1.616 & \multirow[t]{2}{*}{0} & \multirow[t]{2}{*}{1} & \multirow[t]{2}{*}{ NS } \\
\hline & Apex locator & 23.500 & 1.616 & & & \\
\hline \multirow{2}{*}{$\begin{array}{l}\text { Group } 9 \\
\text { (Green T) }\end{array}$} & Radiographic & 23.150 & 2.109 & 0 & 1 & NS \\
\hline & Apex locator & 23.150 & 2.109 & & & \\
\hline Group 10 & Radiographic & 23.700 & 1.829 & 0.5433 & 0.5936 & NS \\
\hline (Lemon) & Apex locator & 23.250 & 1.875 & & & \\
\hline Group 11 & Radiographic & 21.800 & 1.989 & 0.4504 & 0.6578 & NS \\
\hline (Tulsi) & Apex locator & 21.400 & 1.983 & & & \\
\hline
\end{tabular}

Abbreviation: SD, standard deviation.

et al. ${ }^{11}$ Also, $2 \%$ Chlorhexidine did not show varying mean difference in readings by both EALs, Jain et al described, because chlorhexidine has affinity toward hydroxyapatite and possess the lowest electroconductivity. ${ }^{2}$

Although there was no statistical difference between all the herbal irrigants, but some variations had been seen with Tulsi solution because of the presence of ursolic acid and carvacrol. As the other herbal irrigants do not pose any kind of electroconductive properties, they can be used as irrigating solutions, according to Rana et al. ${ }^{12}$

Neem, Paul et al said, had ethanolic extract and its antioxidant activity was attributable to the slight difference in measurements. ${ }^{13}$

Lemon had the presence of citric acid, which is effective in clearing the smear layer, thereby acting as a chelating agent responsible for the slight difference in measurements, according to Tewari et al. ${ }^{14}$

\section{Conclusion}

The third generation EAL (Root ZX) can be considered to be accurate across a variety of irrigants commonly used. Although the irrigants and dry conditions influenced the results, the difference was within the clinically acceptable range and statistically not significant. It can be stated that EAL can be the adjunct to radiographs if correct working conditions are used, as it can determine working lengths in both dry and wet canals. It can even be used clinically for the working length determination where radiographs cannot provide the accurate results, especially in cases of maxillary molars where zygomatic arch and maxillary sinus may produce hindrance while taking radiographic measurements.

\section{Conflict of Interest}

None declared. 
Table 2 The mean and SD values of different groups in wet conditions used for working length determination by radiographic and apex locator methods using unpaired $t$-test

\begin{tabular}{|c|c|c|c|c|c|c|}
\hline \multicolumn{2}{|c|}{ Groups } & Mean & SD & t Value & $p$-Value & Status \\
\hline \multirow{2}{*}{$\begin{array}{l}\text { Group } 1 \\
\text { (dry) }\end{array}$} & Radiographic & 22.950 & 1.770 & \multirow[t]{2}{*}{0.1265} & \multirow[t]{2}{*}{0.9007} & \multirow[t]{2}{*}{ NS } \\
\hline & Apex locator & 22.850 & 1.764 & & & \\
\hline \multirow{2}{*}{$\begin{array}{l}\text { Group } 2 \\
\text { (saline) }\end{array}$} & Radiographic & 23.550 & 1.615 & \multirow[t]{2}{*}{0.0673} & \multirow[t]{2}{*}{0.9471} & \multirow[t]{2}{*}{ NS } \\
\hline & Apex locator & 23.500 & 1.707 & & & \\
\hline \multirow{2}{*}{$\begin{array}{l}\text { Group } 3 \\
\left(\mathrm{H}_{2} \mathrm{O}_{2}\right)\end{array}$} & Radiographic & 21.800 & 1.988 & \multirow[t]{2}{*}{1.309} & \multirow[t]{2}{*}{0.207} & \multirow[t]{2}{*}{ NS } \\
\hline & Apex locator & 20.600 & 2.110 & & & \\
\hline \multirow{2}{*}{$\begin{array}{l}\text { Group } 4 \\
(\mathrm{NaOCl})\end{array}$} & Radiographic & 22.150 & 2.460 & \multirow[t]{2}{*}{1.2473} & \multirow[t]{2}{*}{0.2283} & \multirow[t]{2}{*}{ NS } \\
\hline & Apex locator & 23.500 & 2.380 & & & \\
\hline \multirow{2}{*}{$\begin{array}{l}\text { Group } 5 \\
(\mathrm{CHX})\end{array}$} & Radiographic & 21.550 & 1.930 & \multirow[t]{2}{*}{0.3558} & \multirow[t]{2}{*}{0.7261} & \multirow[t]{2}{*}{ NS } \\
\hline & Apex locator & 21.250 & 1.840 & & & \\
\hline \multirow{2}{*}{$\begin{array}{l}\text { Group } 6 \\
\text { (EDTA) }\end{array}$} & Radiographic & 23.100 & 2.480 & \multirow[t]{2}{*}{0.1002} & \multirow[t]{2}{*}{0.9213} & \multirow[t]{2}{*}{ NS } \\
\hline & Apex locator & 22.990 & 2.430 & & & \\
\hline \multirow{2}{*}{$\begin{array}{l}\text { Group } 7 \\
\text { (Neem) }\end{array}$} & Radiographic & 22.200 & 2.070 & \multirow[t]{2}{*}{0.1299} & \multirow[t]{2}{*}{0.8991} & \multirow[t]{2}{*}{ NS } \\
\hline & Apex locator & 22.080 & 2.060 & & & \\
\hline \multirow{2}{*}{$\begin{array}{l}\text { Group } 8 \\
\text { (Aloe V) }\end{array}$} & Radiographic & 23.500 & 1.610 & \multirow[t]{2}{*}{0} & \multirow[t]{2}{*}{1} & \multirow[t]{2}{*}{ NS } \\
\hline & Apex locator & 23.500 & 1.610 & & & \\
\hline \multirow{2}{*}{$\begin{array}{l}\text { Group } 9 \\
\text { (Green T) }\end{array}$} & Radiographic & 23.150 & 2.100 & 0 & 1 & NS \\
\hline & Apex locator & 23.150 & 2.100 & & & \\
\hline Group 10 & Radiographic & 23.700 & 1.828 & 0.4229 & 0.6774 & NS \\
\hline & Apex locator & 23.360 & 1.767 & & & \\
\hline Group & Radiographic & 21.800 & 1.988 & 0.674 & 0.5089 & NS \\
\hline (Tulsi) & Apex locator & 21.200 & 1.993 & & & \\
\hline
\end{tabular}

Abbreviation: SD, standard deviation.

\section{References}

1 Reynoso RF, Nazario RN, Rodriguez J, Bittencourt BF, Dominguez JA. Influence of irrigant solutions and apex locators in working length determination. J Oral Health Dental Sciences 2017;1(1):1-4

2 Jain S, Kapur R. Comparative evaluation of accuracy of two electronic apex locators in the presence of various irrigants: an in vitro study. Contemp Clin Dent 2012;3(Suppl 2): S140-S145

3 Jain P, Ranjan M. Role of herbs in root canal irrigation-A review. J Pharmacy Biological Sciences 2014;9(2):1-5

4 Joshi C, Ponnappa KC. Effect of various irrigating solutions on working length determination by electronic apex locator: in vitro study. J Int Oral Health 2011;3(5):59-66

5 Kaufman AY, Keila S, Yoshpe M. Accuracy of a new apex locator: an in vitro study. Int Endod J 2002;35(2):186-192

6 Haffner C, Folwaczny M, Galler K, Hickel R. Accuracy of electronic apex locators in comparison to actual length-an in vivo study. J Dent 2005;33(8):619-625

7 Alves AMH, Felippe MC, Felippe WT, Rocha MJ. Ex vivo evaluation of the capacity of the Tri Auto ZX to locate the apical foramen during root canal retreatment. Int Endod J 2005;38(10):718-724
8 Goel Y, Acharya RS, Kundabala M, Ballal V. A comparative evaluation of the accuracy of third generation electronic apex locator (Root ZX) in presence of various intracanal irrigants. J Endod 2006; 18:28-33

9 Khattak O, Raidullah E, Francis ML. A comparative assessment of the accuracy of electronic apex locator (Root ZX) in the presence of commonly used irrigating solutions. J Clin Exp Dent 2014;6(1):e41-e46

10 Dollar, Mann JS, Gumber DS, Khurana NS, Vizo K, SumanA. A comparative assessment of the accuracy of electronic apex locator (Root ZX II) in presence of different irrigating solutions: An in- vitro study. Int J Curr Res2017;9(7):54774-54778

11 Mull JP, Manjunath V, Manjunath M. Comparison of accuracy of two electronic apex locators in the presence of various irrigants: An in vitro study. J Conserv Dent 2012;15(2):178-182

12 Rana AA, Parekh V, Patel SB, Somani M. Comparative evaluation of accuracy of two different electronic apex locators in presence of various herbal irrigating solutions: an in vitro study. J of Dent and Med Sci 2017;16(7):40-44

13 Paul J, Gopalkrishnan M, Kamath D, Joseph R. Herbal root canal irrigants: a review. J Odontol Res 2015;3(1):9-14

14 Tewari KR, Kapoor B, Mishra KS, Kumar A. Role of herbs in endodontics. J Oral Research Review 2016;8(2):95-99 